\title{
Designed and real hydraulic load of household wastewater treatment plants
}

\author{
Piotr M. BUGAJSKI ${ }^{1) A B C D} \bowtie$, Karolina KUREK ${ }^{2) \text { BDF }}$, \\ Dariusz MLYŃSKI $^{3) C D E}$, Agnieszka OPERACZ ${ }^{4) ~ D E F ~}$
}

\author{
1), 2), 3), 4) University of Agriculture of Krakow, Department of Sanitary Engineering and Water Management, al. Mickiewicza 24/28, \\ 30-059, Kraków, Poland \\ 1) orcid.org/0000-0002-6891-7953; e-mail: p.bugajski@urk.edu.pl \\ 2) orcid.org/0000-0003-2944-9656; e-mail: k.kurek@urk.edu.pl \\ 3) orcid.org/0000-0002-8925-2591; e-mail: d.mlynski@urk.edu.pl \\ 4) orcid.org/0000-0002-1717-1661; e-mail: a.operacz@urk.edu.pl
}

For citation: Bugajski P.M., Kurek K., Młyński D., Operacz A. 2019. Designed and real hydraulic load of household wastewater treatment plants. Journal of Water and Land Development. No. 40 (I-III) p. 155-160. DOI: 10.2478/jwld-2019-0017.

\begin{abstract}
The paper presents the results of the analysis concerning the verification of the actual hydraulic load and the load of organic pollutants compared to the conditions designed for 4 household wastewater treatment plants. The researches were carried out in the annual period from May 2015 to April 2016. Based on the conducted analysis, it was found that objects act as underloaded hydraulically and the actual inflow of sewage to the analysed objects during the research period ranged from $7.3 \%$ to $32.7 \%$ in relation to the inflow assumed in the project. Furthermore, in the case of loading the treatment plant with the load of pollutants expressed as $P E$, it was fund that the actual $P E$ values were lower than assumed in the project. Therefore, it is important that the sizes of the series of household sewage treatment plants were selected depending on the individual conditions of household, i.e. the number of inhabitants or the amount of consumed water.
\end{abstract}

Key words: household wastewater treatment plants, hydraulic load, inflow per inhabitant (person), population equivalent

\section{INTRODUCTION}

One of the basic factors indicating the level of civilization in society is the state of development of systems for discharge and disposal of sewage [MESTER et al. 2017; OBARSKA-PEMPKOWIAK et al. 2015; PAWELEK 2016]. In Poland, despite the numerous investments in wastewater management carried out in recent years in the areas of rural and urban-rural communes, currently only $40.3 \%$ of residents of non-urbanized areas discharge and dispose of sewage in collective systems, while in cities - 90\% [GUS 2017]. Additional, in the rural areas, where it is economically justified, there are approx. 217 thousand household sewage treatment plants [GUS 2017]. According to the growth trend in recent years, there are around 22.000 household sewage treatment plants in Poland in various treatment technologies, and forecasts indicate that the number of such facilitates in the next 10-15 years will amount to 500,000 units. At the same time, it is important that during the selection of a treatment technology for small amounts of wastewater, it is necessary to be guided not only economic reasons, but also ecological and technical reasons. Users should choose such objects, which are wastewater treatment plants, not only in name, but also fulfill their functions [CHMIELOWSKI 2016; JAWECKI et al. 2016; JÓźWIAKOWSKI et al. 2015; 2018; WĄSIK, CHMIELOWSKI 2017]. A common phenomenon in rural or urban-rural communes is the selection of one type of sewage treatment plant for all houses in the tender procedure for household sewage treatment plants. During the exploitation of this type of sewage treatment plant, this results in too low or too high hydraulic load, which translates into the effectiveness of eliminating pollution from sewage. 
The aim of the study was to verify (compare) the actual amount of treated sewage to the capacity assumed in projects in 4 household wastewater treatment plants serving single-family houses. These plants were named in the work as A, B, C and D. Households with wastewater treatment plants are located on the area of the commune of Pałecznica in the district of Proszowice, the Małopolska voivodeship $\left(50^{\circ} 17^{\prime} \mathrm{N}, 20^{\circ} 17^{\prime} \mathrm{E}\right)$. The comparison of flow capacity was determined on the basis of two design parameters, i.e. average daily flow $(Q)$ and population equivalent $(P E)$.

\section{MATERIALS AND METHODS}

The researches were conducted in 4 household wastewater treatment plants serving households, in which practically the entire amount of consumed waster goes to wastewater treatment plants. The amount of sewage flowing into individual sewage treatment plants was determined on the basis of the readings of water meters regarding the amount of consumed water. Farms, in which there is no animal or agricultural production and water is used only for living purposes of residents, were selected for these studies. Therefore, the so-called non-returnable water consumption was not observed [BERGEL 2005].

In individual buildings, readings of water meters were collected on the last day of each month, so that it was possible to determine the monthly consumption and daily water consumption, as the daily average value for each analysed month. This enabled to determine the amount of incoming sewage to the treatment plant. The researches were carried out in the annual period from May 2015 to April 2016. In order to calculate the $P E$ parameter in each of the analysed sewage treatment plant, raw sewage was collected (each month) from the first chamber of an initial settling tank. This procedure enables to determine the $\mathrm{BOD}_{5}$ value.

Population equivalent $(P E)$ was calculated from the formula:

$$
P E=\frac{Q_{\text {a.d. }} \cdot \mathrm{BOD}_{5}}{U L_{\mathrm{BOD} 5}}
$$

Where: $Q_{\text {a.d. }}=$ average daily flow of sewage $\left(\mathrm{m}^{3} \cdot \mathrm{d}^{-1}\right)$, $\mathrm{BOD}_{5}=$ value in raw sewage $\left(\mathrm{g} \cdot \mathrm{m}^{-3}\right), U L_{\mathrm{BOD} 5}=$ unit load for $\mathrm{BOD}_{5}$ equal $\left(60 \mathrm{~g} \cdot\right.$ person $\left.^{-1} \cdot \mathrm{d}^{-1}\right)$.

The analysis of raw sewage was conducted in the Laboratory of Water and Wastewater Assessment, located at the Faculty of Environmental Engineering and Geodesy of the University of Agriculture in Kraków. The value of $\mathrm{BOD}_{5}$ in raw sewage was determined in accordance with PN-EN 1899-1:2002 and PN-EN 25814:1999.

Characteristics of households. The house " $A$ " is inhabited by four permanent residents, including to adults and two children. The residential building is equipped with the installation of cold and hot water supplied to the pointof-use in kitchen and bathroom. Residents occasionally use water to wash cars. Due to the marginal use of water for other purposes than housing purposes, the analytical part of the work took into account that $100 \%$ of the consumed water goes to the wastewater treatment plant.
The house " $\mathrm{B}$ " is inhabited by six permanent residents, including four adults and two children. The residential building is equipped with the installation of cold and hot water supplied to the point-of-use in kitchen and bathroom. Residents additionally use water for washing cars and for watering the backyard vegetable garden in the period from July to August. After consultations with residents, it was estimated that the amount of water not reaching the treatment plant in the period from July to August is $10 \%$.

The house " $C$ " is inhabited by two permanent residents in the retirement age. The residential building is the oldest of the analysed buildings and it is equipped with the installation of cold and hot water supplied to the point-of-use in kitchen and bathroom. Residents do not use water for other purposes than housing purposes, so it was assumed that $100 \%$ of consumed water goes to wastewater treatment plant.

The house " $\mathrm{D}$ " is inhabited by two young persons in working age. The residential building is the newest of all the described buildings and it was put into service one year before the rests. The residential building is equipped with the installation of cold and hot water supplied to the point-of-use in kitchen and bathroom. In this household, it was assumed that $100 \%$ of consumed water goes to sewage treatment plant, because there is no the so-called non-returnable water consumption.

Characteristics of wastewater treatment plant. The analysed household sewage treatment plants in all households are characterized by the same type. They are socalled container mechanical and biological wastewater treatment plants with activated sludge technology. The technological line of the treatment plant consists in a mechanical part from a two-chamber septic tank and in the biological part from the aeration chamber (biological reactor with activated sludge) and secondary settling tank combined with the Imhoff funnel. The treatment plant is designed for characteristic design parameters:

- $Q_{\text {a.d. }}=1.5 \mathrm{~m}^{3} \cdot \mathrm{d}^{-1}$

- $P E=12$ person.

\section{RESULTS}

In the first part of the analysis, the results concerning the amount of actually flowing wastewater for individual buildings were developed and compared with the inflow assumed in the project. The average daily and individual (per inhabitant) inflow of sewage were analysed.

In the case of the sewage treatment plant in the house "A" inhabited by four-person family, the average daily flow of sewage to the sewage treatment plant in the analysed period amounted to $0.30 \mathrm{~m}^{3} \cdot \mathrm{d}^{-1}$. This flow was lower than the planned treatment plant's flow capacity by $80 \%$. In the examined period, in individual months, the average daily flow of sewage was uneven and ranged from 0.24 $\mathrm{m}^{3} \cdot \mathrm{d}^{-1}$ (in June, March and April) to $0.44 \mathrm{~m}^{3} \cdot \mathrm{d}^{-1}$ in September. The coefficient of variation for the analysed flows was $C v=0.21$ and according to the scale [MUCHA 1994], the analysed flows were at the level of small variation. The characteristic average daily flows of sewage in individual 


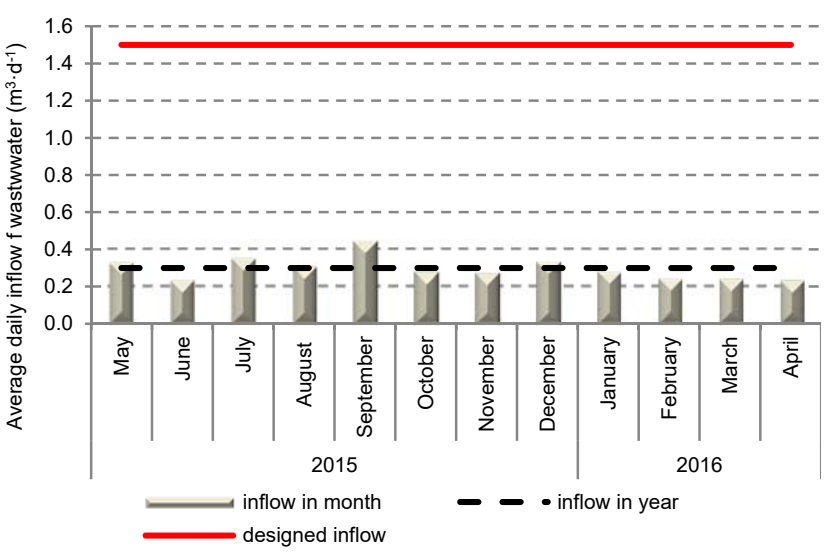

Fig. 1. Characteristic average daily inflows of wastewater from house "A"; source: own study

months along with the medium flow and flow projected from the house "A" are presented in Figure 1.

The individual flow of sewage to the sewage treatment plant in the house " $A$ " ranged from $58.8 \mathrm{dm}^{3} \cdot$ person $^{-1} \cdot \mathrm{d}^{-1}$ recorded in April to $110.9 \mathrm{dm}^{3} \cdot$ person $^{-1} \cdot \mathrm{d}^{-1}$ in September. The average daily unit sewage flow in the period of the analysed 12 months was $74.3 \mathrm{dm}^{3} \cdot$ person $^{-1} \cdot \mathrm{d}^{-1}$. The difference between the minimum and maximum flow was 36.6 $\mathrm{dm}^{3} \cdot$ person $^{-1} \cdot \mathrm{d}^{-1}$. The individual flows of wastewater from the house " $A$ " in individual months and in the annual period are presented in Figure 2.

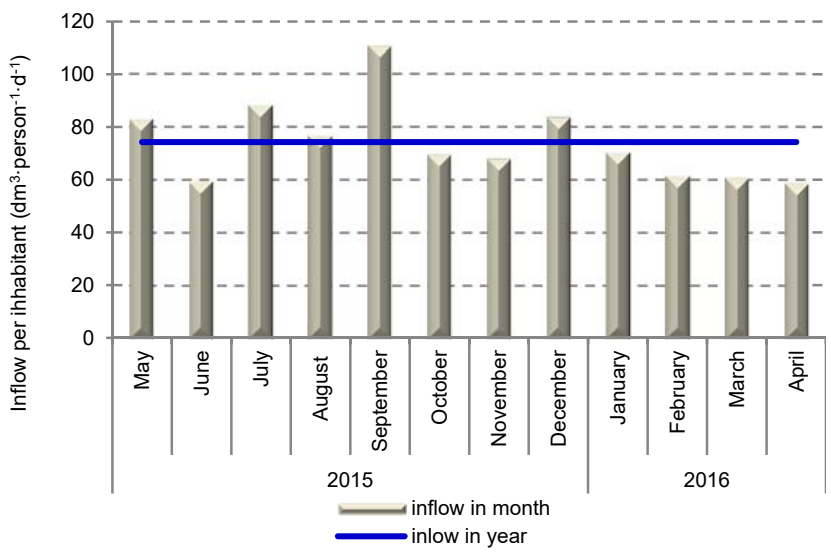

Fig. 2. Inflow of wastewater per inhabitant from house "A"; source: own study

For the sewage treatment plant installed on the house "B" inhabited by six-member family, during the study period, the average daily flow of sewage ranged from 0.35 in March to $0.70 \mathrm{~m}^{3} \cdot \mathrm{d}^{-1}$ in July. Therefore, the difference between the minimum and maximum flow was $0.35 \mathrm{~m}^{3} \cdot \mathrm{d}^{-1}$. The coefficient of variation for the analysed flows was $C v$ $=0.20$ and according to the scale [MUCHA 1994], the analysed flow was at the level of small variation. The average daily annual flow of sewage amounted to $0.49 \mathrm{~m}^{3} \cdot \mathrm{d}^{-1}$ and it was lower that the flow assumed in the project by $67.3 \%$. The characteristic average daily flows of sewage in individual months along with the medium flow and the flow planned from the house " $\mathrm{B}$ " are presented in Figure 3.

The individual flow of sewage to the sewage treatment plant in the house " $B$ " ranged from $56.8 \mathrm{dm}^{3} \cdot$ person $^{-1} \cdot \mathrm{d}^{-1}$

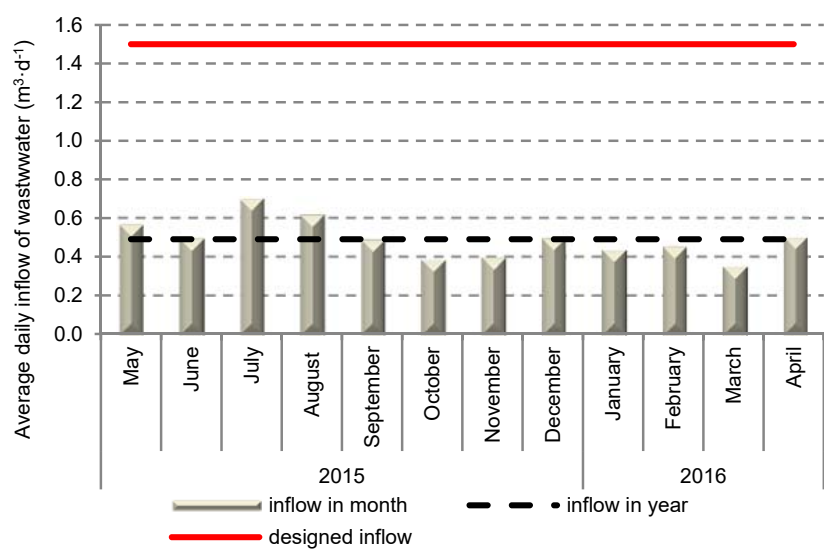

Fig. 3. Characteristic average daily inflows of wastewater from house "B"; source: own study

recorded in March to $117.1 \mathrm{dm}^{3} \cdot$ person $^{-1} \cdot \mathrm{d}^{-1}$ in July. The average daily unit sewage flow in the period of the analysed 12 months was $82.2 \mathrm{dm}^{3} \cdot$ person $^{-1} \cdot \mathrm{d}^{-1}$. The difference between the minimum and maximum flow was 58.5 $\mathrm{dm}^{3} \cdot$ person $^{-1} \cdot \mathrm{d}^{-1}$. The individual flows of wastewater from the house " $\mathrm{B}$ " in individual months and in the annual period are presented in Figure 4.

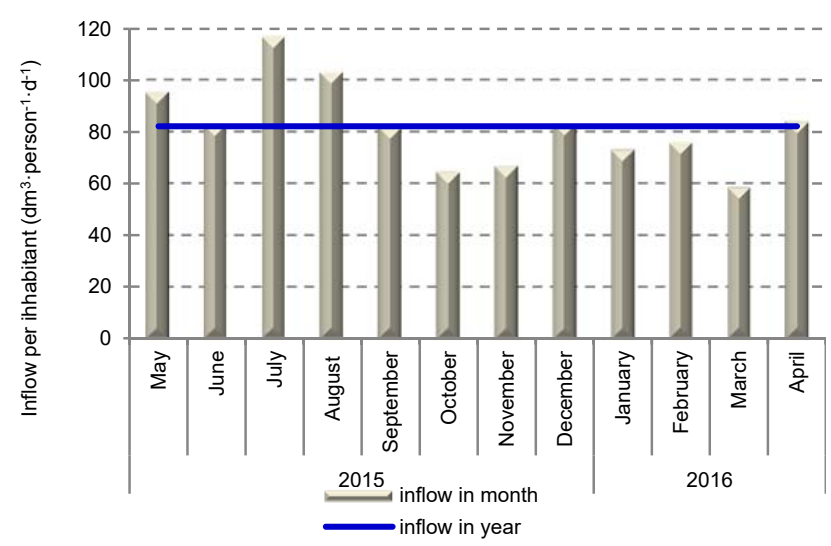

Fig. 4. Inflow of wastewater per inhabitant from house "B"; source: own study

In the case of the house " $\mathrm{C}$ " inhabited by two older people, the average daily flow of sewage oscillated between 0.08 and $0.13 \mathrm{~m}^{3} \cdot \mathrm{d}^{-1}$ in May and January, respectively. The difference between the minimum and maximum flow was $0.05 \mathrm{~m}^{3} \cdot \mathrm{d}^{-1}$. The coefficient of variation for the analysed flow was lower than in the previous cases and amounted to $C v=0.12$ and according to the scale [MUCHA 1994], this flow was at the level of small diversity. The analysed sewage treatment plant was hydraulically loaded in only $7.3 \%$ in relation to the load assumed in the project. The characteristic average daily flow of sewage in individual months along with the medium flow and the flow projected from the house "C" are presented in Figure 5.

In the analysed house "C", the individual flow of sewage to the treatment plant oscillated from 41.1 to 66.7 $\mathrm{dm}^{3} \cdot$ person $^{-1} \cdot \mathrm{d}^{-1}$ in May and January, respectively. Therefore, the difference between the minimum and maximum flows was $25.6 \mathrm{dm}^{3} \cdot$ person $^{-1} \cdot \mathrm{d}^{-1}$. The average daily unit sewage flow in the period of the analysed 12 months was 


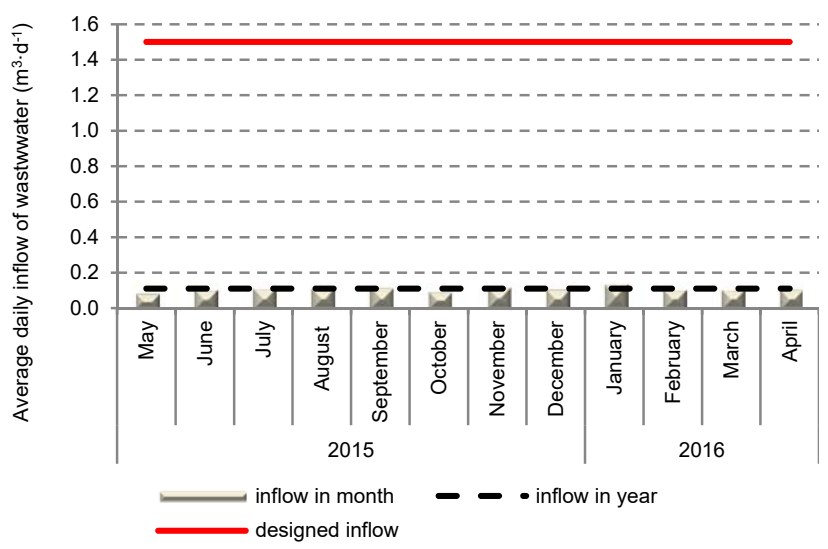

Fig. 5. Characteristic average daily inflows of wastewater from house "C"; source: own study

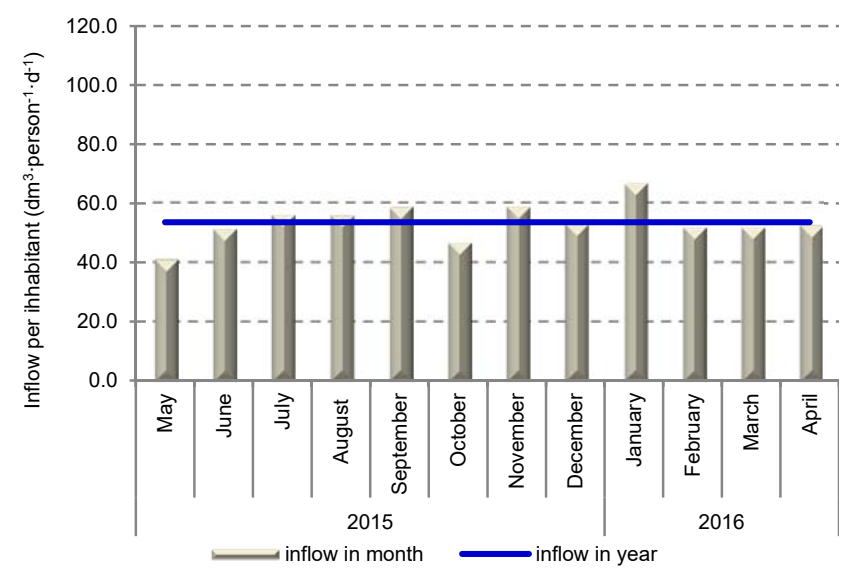

Fig. 6. Inflow of wastewater per inhabitant from house "C"; source: own study

$53.6 \mathrm{dm}^{3} \cdot$ person $^{-1} \cdot \mathrm{d}^{-1}$. The individual flows of wastewater from the house " $\mathrm{C}$ " in individual months and in the annual period are presented in Figure 6.

In the last analysed house " $D$ ", which (like the previous house) is inhabited by two persons, but with the difference that there are young people of working age, the average daily flow of sewage ranged from $0.21 \mathrm{~m}^{3} \cdot \mathrm{d}^{-1}$ in November to $0.45 \mathrm{~m}^{3} \cdot \mathrm{d}^{-1}$ in May. The difference between the minimum and maximum flow was $0.24 \mathrm{~m}^{3} \cdot \mathrm{d}^{-1}$. The coefficient of variation for the analysed flows was $C v=0.19$ and according to the scale [MUCHA 1994] it was diversification at a small level. In the annual period, the average daily flow of sewage to the treatment plant was $0.32 \mathrm{~m}^{3} \cdot \mathrm{d}^{-1}$, so the treatment plant was hydraulically underloaded at $78.7 \%$. The characteristic average daily flows of sewage in individual months along with the medium inflow and the flow planned from the house "D" are presented in Figure 7.

In the analysed house " $D$ ", the unit flow of sewage to the treatment plant ranged from $103.7 \mathrm{dm}^{3} \cdot$ person $^{-1} \cdot \mathrm{d}^{-1}$ in November to $223.8 \mathrm{dm}^{3} \cdot$ person $^{-1} \cdot \mathrm{d}^{-1}$ in August. The difference between the minimum and maximum flow was $120.1 \mathrm{dm}^{3} \cdot$ person $^{-1} \cdot \mathrm{d}^{-1}$. The average daily unit flow of sewage in the period of analysed 12 months in this house amounted to $162.3 \mathrm{dm}^{3} \cdot$ person ${ }^{-1} \cdot \mathrm{d}^{-1}$ and it was the highest of all analysed farms. The individual flows of wastewater from the house " $\mathrm{C}$ " in individual months and in the annual period are presented in Figure 8.

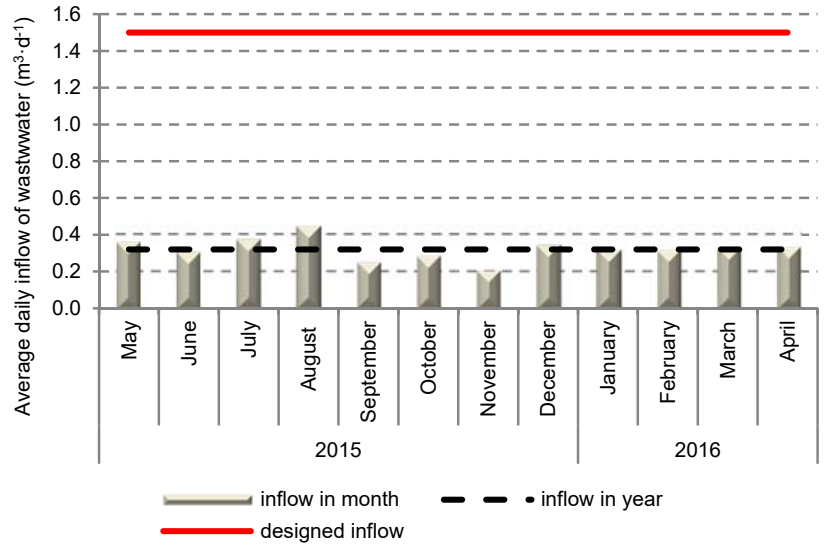

Fig. 7. Characteristic average daily inflows of wastewater from house "D"

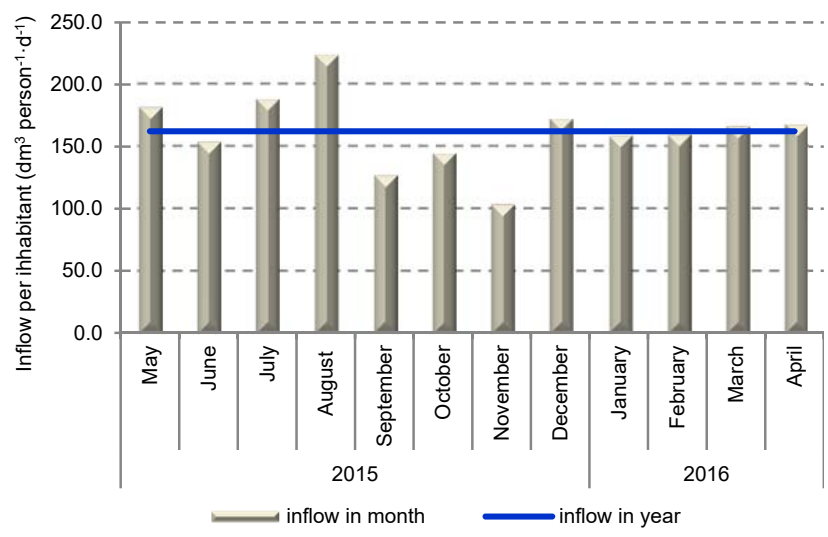

Fig. 8. Inflow of wastewater per inhabitant from house "C"; source: own study

In the second part of the analysis, based on the $\mathrm{BOD}_{5}$ values in raw sewage and the amount of incoming sewage, the actual project parameter regarding the selection of the type of sewage treatment plant (i.e. the $P E$ - population equivalent) was determined. Moreover, it was compared with the $P E$ assumed in the project.

In individual houses, $\mathrm{BOD}_{5}$ values in raw sewage were varied. $\mathrm{BOD}_{5}$ value in the "A" house oscillated from 500 to $1000 \mathrm{~g} \cdot \mathrm{m}^{-3}$, in the "B" house $-\mathrm{BOD}_{5}$ values ranged from 500 to $1850 \mathrm{~g} \cdot \mathrm{m}^{-3}$, in the " $\mathrm{C}$ " house - fluctuations in $\mathrm{BOD}_{5}$ values ranged from 350 to $1300 \mathrm{~g} \cdot \mathrm{m}^{-3}$ and in case of " $\mathrm{D}$ " house, fluctuations in $\mathrm{BOD}_{5}$ values ranged from 150 to $260 \mathrm{~g} \cdot \mathrm{m}^{-3}$.

In the case of the sewage treatment plant for the house "A", on the basis of $\mathrm{BOD}_{5}$ values in raw sewage and the average daily amount of incoming sewage, it was found that $\mathrm{PE}$ in individual months ranged from 3.7 to 8.8 and in annual terms $P E$ for this house amounts to 5.6 , so the rounded value is $6 . P E$ assumed in the project is higher by $50 \%$ compared to the actual $P E$. On the "B" house, $P E$ ranged from 3.2 to 7.7 in individual months and the average $P E$ in the annual period is 7.7 (the value in the amount of 8 can be assumed). $P E$ assumed in the project is $35.8 \%$ higher than the actual $P E$. On the " $\mathrm{C}$ " house, the calculated $P E$ value varies in individual months from 0.7 to 2.5 , while for the annual period - it is 1.2. Therefore, the value of $P E$ in the amount of 1 can be assumed. The actual $P E$ is lower 
than the assumed value in the project by almost $92 \%$. In the case of the last of the analysed house "D", the $P E$ calculated for individual months ranged from 0.5 to 1.5 , and the average annual value of PE reached 1.1. It has been assumed that the real $P E$ for this house is 1 .

\section{DISCUSSION}

According to KACZOR [2011; 2012], ANDRAKA and DZIENIS [2013], as well as MŁYŃSKI et al. [2017], the adequate (according to the design assumptions) hydraulic load of a sewage treatment plant plays a key role in the wastewater treatment process. Overloading or underloading of the sewage treatment plant is the cause of disruption of wastewater treatment processes.

During the analysis of actual and planned hydraulic load of four home sewage treatment plants, it is stated that all objects were hydraulically underloaded to a different degree. The basic reasons for this fact at the stage of selecting the type of sewage treatment plant is incorrect specification of the unit amount of wastewater and the erroneous determination of the average daily amount of incoming sewage from a given house. In recent years, generally, during the design of sewage systems in non-urbanized areas, a unit amount per inhabitant of $150 \mathrm{dm}^{3} \cdot \mathrm{d}^{-1}$ is accepted [Bergel 2005; Bergel, KaCZOR 2007; ĆWIERTNIA 2004; HeIDRICH 1998; MuCHA, MiKOSZ 2009]. The studies conducted by BugAJSKI and BERGEL [2009], BERGEL [2005], PAWĘSKA et al. [2013] show that the unit quantity of sewage assumed at the level of $150 \mathrm{dm}^{3} \cdot \operatorname{person}^{-1} \cdot \mathrm{d}^{-1}$ is too large in comparison to the actual quantity of sewage, which (in practice) does not exceed $100 \mathrm{dm}^{3} \cdot$ person $^{-1} \cdot \mathrm{d}^{-1}$. Similar conclusions regarding the unit quantity of water consumed in other countries were presented by DIAS et al. [2018] and GURAGAI et al. [2018]. An additional problem in determining the actual amount of sewage flowing out is the so-called non-returnable water consumption, i.e. water, which does not go to the sewage system after consumption. According to the research conducted by BERGEL [2005], the non-returnable water consumption constitutes about $10-20 \%$ of the daily water consumption. Therefore, during the determination of the amount of sewage generated on the basis of water consumption readings from the water meter in rural areas, such an event should be anticipated and taken into account [JÓźWIAKOWSKI 2017]. The erroneously determined average daily amount of sewage has a direct impact on the calculated $P E$. When this design parameter is taken into account in the selection of the type of wastewater treatment plant, there is a mistake of underloading or overloading with the load of organic pollutants expressed in $\mathrm{BOD}_{5}$ [BUGAJSKI et al. 2017].

\section{CONCLUSIONS}

On the basis of the conducted analysis regarding the hydraulic load of four household sewage treatment plants in the aspect of verification of design assumptions, it was found that the objects act as hydraulically underloaded. During the research period, the actual sewage flow to the analysed facilities ranged from $7.3 \%$ to $32.7 \%$ in relation to the flow assumed in the project. Furthermore, in the case of the assumed $P E$ design parameter, the objects were underloaded with a load of pollutions. The actual $P E$ (calculated on the basis of the $\mathrm{BOD}_{5}$ value and the average daily amount of sewage) ranged from 1 to 8 at the assumed designed value $P E=12$. In order to prevent the phenomenon of hydraulic underloading of household sewage treatment plants due to the small number of incoming sewage, each type of farm should be treated individually when choosing the type of objects. It means the determination of the actual number of inhabitants and the specificity of using water supply and sewage facilities in residential buildings. However, if possible, the number of incoming sewage should be determined on the basis of the amount of consumed water (readings from the water meter). Acceptance of theoretical values results in hydraulic underloading of the objects. Additionally, it is recommended to use the so-called small centralization (i.e. connection of a few or a dozen buildings to one wastewater treatment plant where it is possible due to topographical and social reasons) instead of the construction of a dozen or so household sewage treatment plants.

\section{REFERENCES}

ANDRAKA D., DzIENIS L. 2013. Modelowanie ryzyka w eksploatacji oczyszczalni ścieków [Modeling of risk in the operation of wastewater treatment plants]. Rocznik Ochrona Środowiska. Vol. 15 p. 1111-1125.

BERGEL T. 2005. Objętość ścieków odprowadzanych z gospodarstw wiejskich do kanalizacji w zależności od struktury zużycia wody wodociągowej [The volume of sewage discharged from rural households to sewerage depending on the structure of water consumption]. PhD Thesis. AR w Krakowie. Wydział Inżynierii Środowiska i Geodezji pp. 175.

BERGEL T., KACZOR G. 2007. The volume of wastewater discharged from rural households to the sewer system in the light of tap water consumption structure. Polish Journal of Environmental Studies. Vol. 16. No. 2A. P. II p. 109-112.

BugAJSKi P., BERGEL T. 2009. Niedociążenia hydrauliczne przydomowych oczyszczalni ścieków [Underloading of hydraulic in domestic sewage treatment plant]. Infrastruktura i Ekologia Terenów Wiejskich. No. 5 p. 147-154.

Bugajski P., Nowobilska-Majewska E., KureK K. 2017. The variability of pollution load of organic, biogenic and chromium ions in wastewater inflow to the treatment plant in Nowy Targ. Journal of Water and Land Development. No. 35 p. 1117. DOI 10.1515/jwld-2017-0063.

CHMIElowski K. 2016. Zagadnienia prawne związane z POŚ cz. I [Legal issues related to HTP - part I]. Przegląd Komunalny. Nr 2 p. 58-60.

ĆWIERTNIA R. 2004. Prawidłowy wskaźnik jednostkowego zapotrzebowania wody - podstawa optymalnego zaprojektowania sieci wod.-kan. oraz obiektów wodociągowych i kanalizacyjnych [Correct unit water demand indicator - the basis for optimal design of the water and sewage network and water supply and sewage systems]. Forum Eksploatatora. $\mathrm{Nr} 2$ p. $14-17$.

Dias T.F., Kalbusch A., Henning E. 2018. Factors influencing water consumption in buildings in southern Brazil. Journal of Cleaner Production. No. 184 p. 160-167.

Guragai B., Hashimoto T., Oguma K., TAkizawa S. 2018. Data logger-based measurement of household water consumption and micro-component analysis of an intermittent water supply 
system. Journal of Cleaner Production. No. 197 p. 11591168.

GUS 2017. Infrastruktura komunalna w 2016 roku [Municipal infrastructure in 2016]. Warszawa. Główny Urząd Statystyczny pp. 35.

HEIDRICH Z. 1998. Przydomowe oczyszczalnie ścieków. Poradnik. [Domestic treatment plants. Guide]. Warszawa. Centralny Ośrodek Informacji Budownictwa pp. 220.

JaWECKI B., MarsZaleK J., PAWĘSKa K., SObOTA M., MalCZEWSKA B. 2016. Budowa i funkcjonowanie przydomowych oczyszczalni ścieków w świetle obowiązujących przepisów część 1 [Construction and operation of domestic wastewater treatment plant under the relevant legislation - part 1]. Infrastruktura i Ekologia Terenów Wiejskich. Nr 2/II p. 501-516.

JóźWIAKOWSKI K. 2017. Skuteczność usuwania związków biogennych $\mathrm{w}$ filtrach piaskowych $\mathrm{z}$ poziomym przepływem ścieków [Efficiency of biogenic compounds removal in a sand filters with horizontal flow]. Woda-ŚrodowiskoObszary Wiejskie. T. 17. Z. 4 (60) p. 37-48.

Jóźwiakowski K., Mucha Z., Generowicz A., Baran S., BieLIŃSKA J., WÓJCIK W. 2015. The use of multi-criteria analysis for selection of technology for a household WWTP compatible with sustainable development. Archives of Environmental Protection. Vol. 41. Iss. 3 p. 76-82.

Jóźwiakowski K., Podbrożna D., Kopczacka K., Jaguś M., Marzec M., Listosz A., POChWATKa P., KowalczyK-JuŚKo A., MALIK A. 2018. The state of water and wastewater management in the municipalities of the Roztocze National Park. Journal of Ecological Engineering. Vol. 19. Iss. 2 p. 255-262.

KACZOR G. 2011. Wpływ wiosennych roztopów śniegu na dopływ wód przypadkowych do oczyszczalni ścieków bytowych [Impact of spring snowmelt on inflows to the household sewage treatment plant]. Acta Scientiarum Polonorum (Formatio Circumiectus). Vol. 10. Iss. 2 p. 27-34.

KACZOR G. 2012. Wpływ wód infiltracyjnych i przypadkowych na funkcjonowanie małych systemów kanalizacyjnych [Effect of infiltration and inflow waters on the performance of small sewer systems]. Rozprawa Habilitacyjna. Nr 372. Zeszyty Naukowe Uniwersytetu Rolniczego w Krakowie. Nr 495. ISSN $1899-3486$ pp. 229.

Mester T., Szabó G., Bessenyei É., Karancsi G., Barkóczi N., BALLA D. 2017. The effects of uninsulated sewage tanks on groundwater. A case study in an eastern Hungarian settlement. Journal of Water and Land Development. No. 33 p. 123-129. DOI 10.1515/jwld-2017-0027.

MŁYŃSKi D., ChMielowski K., MŁYŃSKA A. 2017. Analiza zmienności ilościowej ścieków dopływających do wybranych oczyszczalni powiatu sanockiego [The analysis of the quantity variability of the sewage inflowing to the selected wastewater treatment plants of Sanok district]. Acta Scientiarum Polonorum. Formatio Circumiectus. Vol. 16(1) p. 77-90.

Mucha J. 1994. Metody geostatystyczne w dokumentowaniu złóż [Geostatistical methods in documenting deposits]. Skrypt. Kraków. AGH. Katedra Geologii Kopalnianej pp. 155.

Mucha Z., Mikosz J. 2009. Racjonalne stosowanie małych oczyszczalni ścieków z uwzględnieniem kryteriów zrównoważonego rozwoju [Rational application of small wastewater treatment plants according to sustainability criteria]. Czasopismo Techniczne Politechniki Krakowskiej. Nr 2 p. 92-100.

Obarska-PempKowiak H., KoŁecka K., Gajewska M., WojcieCHOWSKA E., OSTOJSKI A. 2015. Zrównoważone gospodarowanie ściekami na przykładzie obszarów wiejskich [Sustainable sewage management in rural areas]. Rocznik Ochrony. $\mathrm{Nr} 17$ p. 585-602.

PAWEŁEK J. 2016. Degree of development and functionality of the water supply and sewage systems in rural Poland. Barometr Regionalny. Analizy i Prognozy. Iss. 14(1) p. 141-149.

PawęSka K., Bawiec A., WŁodek S., Smaga E. 2013. Wstępna analiza średniego zużycia wody $w$ jednorodzinnych gospodarstwach domowych [A preliminary analysis of the average consumption of cold water in single-family houshold]. Infrastruktura i Ekologia Terenów Wiejskich. Nr 1 p. 171-179.

PN-EN 1899-1:2002 - Jakość wody - Oznaczanie biochemicznego zapotrzebowania tlenu po $\mathrm{n}$ dniach (BZTn) [Water quality - Determination of biochemical oxygen demand after $n$ days (BODn) - Part 1].PN-EN 25814:1999. Jakości wody - Badania chemiczne - Substancje nieorganiczne [Water quality Chemical research - Inorganic substances].

WĄSIK E., CHMIElOWSKI K. 2017. Ammonia and indicator bacteria removal from domestic sewage in a vertical flow filter filled with plastic material. Ecological Engineering. Vol. 106. P.t. A p. $378-384$.

\section{Piotr M. BUGAJSKI, Karolina KUREK, Dariusz MLYŃSKI, Agnieszka OPERACZ}

\section{Projektowane a rzeczywiste obciążenie hydrauliczne przydomowych oczyszczalni ścieków}

\section{STRESZCZENIE}

W pracy przedstawiono wyniki analizy dotyczące weryfikacji rzeczywistego obciążenia hydraulicznego oraz obciążenia ładunkiem zanieczyszczeń organicznych w porównaniu z warunkami projektowanymi dla czterech przydomowych oczyszczalni ścieków. Badania prowadzono w rocznym okresie - od maja 2015 r. do kwietnia 2016 r. Na podstawie przeprowadzonej analizy stwierdzono, że obiekty działają jako niedociążone hydraulicznie, a rzeczywisty dopływ ścieków do analizowanych obiektów w okresie badań wyniósł od 7,3\% do 32,7\% w stosunku do dopływu zakładanego w projekcie. Również w przypadku obciążenia oczyszczalni ładunkiem zanieczyszczeń wyrażonych jako RLM, stwierdzono, że rzeczywiste wartości RLM były niższe, niż zakładane w projekcie. Zatem ważne jest, aby wielkości typoszeregów przydomowych oczyszczalni ścieków były dobierane w zależności od indywidualnych uwarunkowań gospodarstw domowych, tj. liczby mieszkańców lub ilości zużywanej wody.

Słowa kluczowe: dopływ jednostkowy, obcią̇enie hydrauliczne, przydomowe oczyszczalnie ścieków, RLM 